\title{
DESNIČIN ZAGREB: \\ UVODNE NAPOMENE
}

\section{Drago Roksandić}

q nanstveni skupovi Desničini susreti 2018.: Zagreb 1924. - 1930. i 1945. - 1967.: društvo, kultura, svakodnevica te Desničini susreti 2019.: Vladan Desnica i Zagreb, 1924. 1930. i 1945. - 1967. istražuju Zagreb u vremenima kada je Vladan Desnica u njemu živio te se ljudski i intelektualno formirao u svojim mladim, odnosno umjetnički stvarao i djelovao u svojim zrelim godinama, sve do smrti u 62. godini života. U obama slučajevima riječ je o Zagrebu, hrvatskome glavnom gradu u dvama poraćima i u dvjema bitno različitim jugoslavenskim državama. Riječ je o Zagrebu koji i u jednim i u drugim godinama proživljava izazove dvaju različitih moderniteta, dvaju različitih odnosa prema tradiciji i dviju različitih logika urbanih imaginacija. Desničini susreti 2014. i Desničini susreti 2015. propitivali su razne vidove međuodnosa Splita i Vladana Desnice, odnosno Vladana Desnice i Splita. Dva voluminozna zbornika svjedočanstvo su o tome što se sve i kako može problematizirati polazeći od problematika (konkretnoga) grada i (konkretnoga) pisca, odnosno (konkretnoga) pisca i (konkretnoga) grada. Stečeno iskustvo omogućilo je suočavanje s još većim, zagrebačkim izazovom u Desničinu slučaju. Nakon 1941. - 1945. godine Desnica više nije živio u Splitu. Ostao je za njega na različite načine vezan, vjerojatno mnogo dublje nego što se to od 1945. do 1967. može razumjeti. Međutim, u Zagrebu je živio u svojim studentskim i, ponovno, u svojim najzrelijim godinama pa su problematike odnosa grada $\mathrm{i}$ umjetnika te umjetnika i grada mnogo složenije i intelektualno zahtjevnije.

Iako, otvoreno rečeno, nismo uspjeli ući u probleme intraurbane komparatistike, tj. u probleme povijesti dviju distinktivnih modernizacija Zagreba, uspjeli smo nizom priloga osigurati dijakronijske interpretacije, odnosno preglede promjena u Gradu koji su slijedili intencije iz ključnog stava pozivnog pisma za Desničine susrete 2018.: „Pored urbane demografije i ekonomike do socijalne, kulturne, ali i političke dinamizacije, vrlo često konfliktne naravi, Zagreb je bio epicentar kreativnog otvaranja prema brojnim onovremenim receptivno-umjetničkim iskustvima i praksama. Istražujući fenomene i procese zagrebačke društvene, kulturne i intelektualne povijesti navedenog razdoblja, namjera je otvoriti dijaloški prostor za njezino komparatističko propitivanje, tj. utvrđivanje sličnosti i razlika, kontinuiteta i diskontinuiteta." Takav je Zagreb zasigurno bio vrlo poticajan izazov kako za mladoga tako i za zrelog Desnicu pa je u takvu gradu i mogao tražiti, provjeravati i ostvarivati svoje kreativne potencijale, što je tema Desničinih susreta 2019.

Ovom prilikom nećemo ulaziti u uobičajenu detaljniju problematizaciju uvrštenih priloga. Učinili su to recenzenti, točnije rečeno, četveročlani recenzentski tim (prof. dr. sc. Igor Borozan /Beograd/, prof. dr. sc. Bojan Đorđević /Beograd/, prof. dr. sc. u m. Dušan Marinković /Zagreb/ i dr. sc. Petar Prelog /Zagreb/). Svaki prilog ocijenila su dvojica recenzenata. Zbornik kao cjelinu također su ocijenila dvojica recenzenata (prof. dr. sc. Dragan Damjanović /Zagreb/ i doc. dr. sc. Vladimir Gvozden /Novi Sad/). Redovito sadržajne recenzije i 
ovaj su put dodatno obogatile dijaloško iskustvo Desničinih susreta, otkrivajući vrijednosti priloga, ali i ukazujući na pitanja koja iziskuju daljnja istraživanja. Sažetke članaka prevela je na engleski jezik profesorica Marija Marčetić.

Cijeli je rukopis lektorirala, konsekventno primjenjujući ista pravopisna načela - osim u slučajevima prilogâ autorâ koji nisu iz Hrvatske - dr. sc. Samanta Paronić. Jednoobrazno je sredila, kada je to bilo potrebno, sve bilješke te popise izvora i literature. Kolegica Paronić napravila je korekturu prijeloma te „Imensko kazalo“. Kolegica Mihaela Marić pomogla je bibliografski kompletirati stanovit broj bilježaka u skladu s tradicionalno ustaljenim „Uputama za pisanje priloga" u zbornicima Biblioteke Desničini susreti.

Na kraju, možemo sa zadovoljstvom reći da je i ovaj zbornik, kao i brojni prethodni, realiziran u odličnoj suradnji s FF pressom Filozofskog fakulteta Sveučilišta u Zagrebu, odnosno s kolegama - urednikom Borisom Buijem i Markom Marakovićem, koji je obavio najveći dio poslova u vezi s pripremom rukopisa za tisak.

U impresumu navedene su ustanove koje su omogućile tiskanje ovog zbornika.

Svima spomenutima Desničini susreti duguju veliku zahvalnost. Osjećam zadovoljstvo što to mogu napisati kao urednik ovog sveska Biblioteke Desničini susreti.

Zagreb, 16. listopada 2019. 


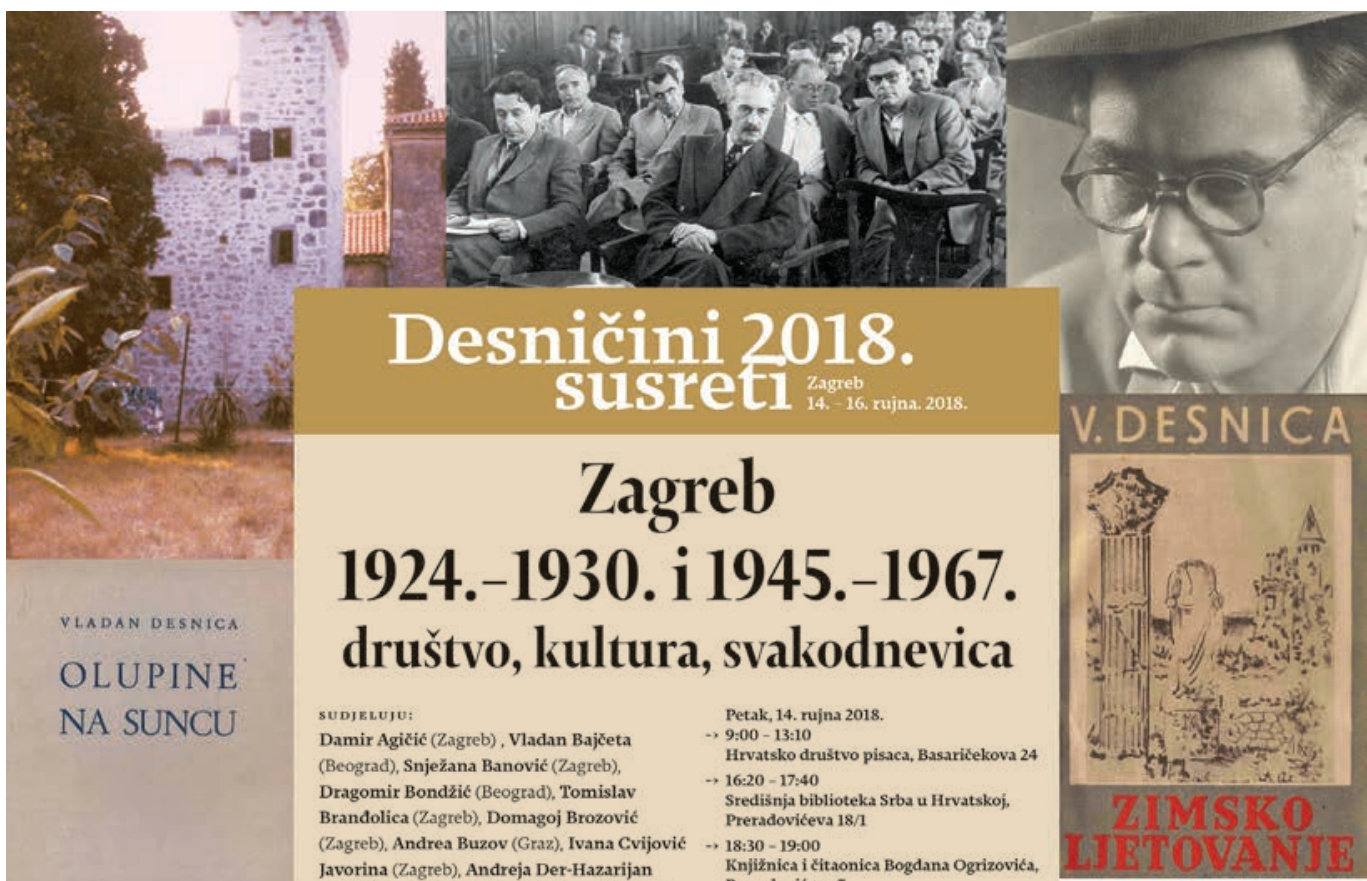

Javorina (Zagreb), Andreja Der-Hazarijan Knjižnica i čitaonica Bogdana Ogrizovica, Vukič (Zagreb), Vinko Drača (Zagreb), Ljerka Preradovićeva 5 Dulibić (Zagreb), Bojan Đorđević (Beograd), $\quad \rightarrow$ 19:00 - 20:30 Knjižnica i čitaonica Bogdana Ogrizovića, Preradoviceva 5 (Zagreb), Hrvoje Gržina (Zagreb), Goran Predstavljanje 16. sveska Biblioteke Hutinec (Zagreb), Vedran Ivanković (Zagreb), Desnißini susreti Zvonko Kovač (Zagreb), Gordana Krivokapić Jovié (Beograd), Marko Lovrić (Zagreb), Lovorka Magaš Bilandžić (Zagreb), Mihaela Marić (Zagreb), Dušan Marinković (Zagreb), Krešimir Mičanović (Zagreb), Andrea Milanko (Zagreb), Magdalena Najbar-Agičić (Zagreb), Ida Ograjsek Gorenjak (Zagreb), Patricia Počanić (Zagreb), Petar Prelog (Zagreb), Iva Pasini Tržec (Zagreb), Monica Priante (Zagreb), Barbara Riman (Ljubljana), Sanja Roíć (Zagreb), Drago Roksandić (Zagreb), Sanja Šakič (Zagreb), Filip Šimetin Šegvić (Zagreb), Nikolina Šimetin Šegvić (Zagreb), Ivana Šubic Kovačevic (Zagreb), Ivica Šute (Zagreb).

Smrt u opusu Vladana Desnice i europskoj kulturi -

poetički, povijesni i fllozofski aspekti (ur. Drago Roksandić i Ivana Cvijovic Javorina), Zagreb 2018

Javorina), Zagreb 2018. o Vladanu Desnici, Zagreb 2018.

Subota, 15. rujna 2018

$\Rightarrow$ 10:00 - 13:00 i1 $15: 00$ - 17:00

Vijećnica Filozofskog fakulteta

Sveučilišsta u Zagrebu, Ivana Luěića 3

Muzej za umjetnost i obrt

Posjet izložbi Šezdesete u Hrvatskoj - mit i stvarnost

Nedjelja, 16, rujna 2018

10:00 - 13:40 i 15:00 - 17:40

Vijećnica Filozofskog fakulteta

Sveucilista u Zagrebu, Ivana Lučića 3

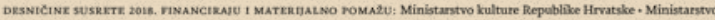

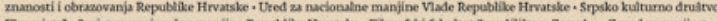

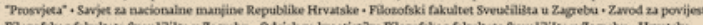

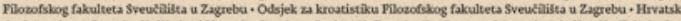

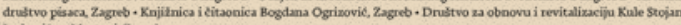
Jankovica - Mostovi, Zageet

INTEGRALNA VERZIJA PROGRAMA:

http:/ckhis.ffzg.unizg.hr/hr/istrazivanja/programi/program-drustveno-humanistickihi-kulturoloskih-istrazivanja-desnicini-susreti/

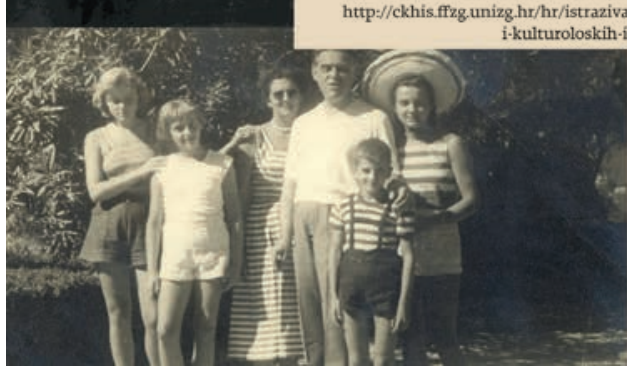

$\gg$ Migud $\ll$

$7 / 1 / 48$

"Često mi pada na um Michelangelova riječ iz jednog pisma Vasariju: 'Non nasce in me pensier che non vi sia dentro scolpita la Morte.' I riječ onog drugog velikog ludog starca: 'Kad je čovjek jednom naučio da misli, ma o čemu mislio, on u stvari uvijek misli na svoju vlastitu smrt.' Svi su filozofi bili takvi! I svi veliki pjesnici, nadodao bih. Smrt je u suštini jedina tema pjesnika. A što im drugo i preostaje, kad već ne mogu biti vječiti ljetopisci života, nego da budu neumorni žreci Smrti?"

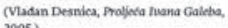

$$
\begin{aligned}
& \text { (swent oredije) } \\
& \text { (Cositouirau. tuth ! - }
\end{aligned}
$$

